\title{
Koksidiosis pada kangguru pohon kelabu (Dendrolagus inustus) di tempat konservasi ex situ
}

\author{
Yusuf Ridwan ${ }^{1, *}$, Arifin Budiman Nugraha ${ }^{1}$, Hammada Raudlowi ${ }^{2}$ \\ ${ }^{1}$ Departemen Ilmu Penyakit Hewan dan Kesehatan Masyarakat Veteriner, Fakultas Kedokteran Hewan, Institut Per- \\ tanian Bogor \\ ${ }^{2}$ Faunaland Ancol, Jakarta Utara
}

\begin{abstract}
ABSTRAK: Koksidiosis merupakan penyakit yang dapat menyerang berbagai jenis hewan termasuk kangguru. Informasi koksidiosis pada kangguru dahan kelabu masih sangat sedikit. Penelitian ini bertujuan untuk melakukan observasi kasus koksidiosis pada kanguru pohon kelabu yang meliputi pengamatan gejala klinis, dan mengidentifikasi jenis koksidia. Hasil observasi pada dua ekor kangguru pohon kelabu menunjukkan penurunan aktivitas, lemah, lesu dan nafsu makan menurun. Hasil pemeriksaan feses menunjukkan kedua hewan menderita koksidiosis dengan rata rata jumlah ookista tiap gram feses sebesar 450 . Hasil identifikasi menunjukkan jenis koksidia yang menginfeksi adalah dari genus Eimeria spp.
\end{abstract}

Kata kunci:

koksidiosis, kangguru pohon kelabu, Eimeria spp.

\section{- PENDAHULUAN}

Kangguru pohon kelabu atau dikenal dengan nama kangguru pohon wakera (Dendrolagus inustus) merupakan satu diantara 6 spesies kangguru pohon yang terdapat di Indonesia (Greves 2005). Penyebarannya dapat ditemukan hampir di seluruh wilayah Papua, meliputi Pegunungan Foja dan Semenanjung kepala burung dan juga terdapat di pulau lepas pantai Yapen, Waigeo, Misool dan Salawati dan Batanta (Leary et al. 2016). Kangguru pohon kelabu merupakan spesies kangguru pohon di Indonesia yang dilindungi. Namun, keberadaan dan jumlah spesies ini semakin berkurang karena perburuan liar dan hilangnya habitat hidupnya. Oleh karena itu, kangguru pohon merupakan hewan yang dilindungi di Indonesia berdasarkan Peraturan Menteri Lingkungan Hidup dan Kehutanan Nomor P.106 tahun 2018 (KLHK 2018). Bahkan kangguru pohon telah masuk kedalam daftar merah IUCN (International Union for Conservation of Nature) dengan katagori rentan (vulnerable).

Satu diantara upaya untuk melestarikan kanguru pohon kelabu adalah melalui konservasi baik in situ maupun ex situ. Beberapa kendala yang dihadapi konservasi ex situ adalah ancaman berbagai penyakit termasuk yang disebabkan oleh parasit koksidia. Koksidiosis merupakan penyakit di saluran pencernaan yang disebabkan oleh infeksi parasit koksidia, salah satunya genus Eimeria spp. Infeksi parasit tersebut telah dilaporkan pada famili Macropodidae termasuk pada bebeberapa kangguru pohon (Barker et al. 1988; Barker et al. 1989; O'Callaghan et al. 1998). Sementara itu, koksidiosis pada kangguru kelabu (Dendrolagus inustus) belum banyak dilaporkan. Mengingat bahaya koksidiosis yang dapat menimbulkan kerugian, dan bahkan kematian pada kangguru, maka penyakit ini perlu mendapat perhatian yang khusus terutama pada kangguru yang dipelihara di ex situ. Tulisan ini membahas kasus koksidiosis pada kangguru kelabu di konservasi ex situ, meliputi jenis koksidia yang menginfeksi, dan gejala klinis yang ditimbulkan.

\section{- BAHAN DAN METODE}

Pemeriksaan dilakukan terhadap dua ekor kangguru dengan jenis kelamin jantan dan betina, masing-masing berumur 3 dan 1,5 tahun. Pemeriksaan diawali dengan mengumpulkan informasi yang diperoleh dari petugas kesehatan dan keeper, meliputi gejala klinis yang dialami kanguru. Gejala klinis yang muncul salah satunya mengarah pada gangguan saluran pencernaan dan diduga disebabkan oleh infeksi parasit. Pemeriksaan dilakukan terhadap feses dari dua kanguru yang dipelihara di tempat konservasi ex situ untuk memastikan adanya infeksi parasit. Pemeriksaan dilakukan dengan menggunakan metode pengapungan sederhana dan McMaster (kuantitatif).

\section{- HASIL DAN PEMBAHASAN}

Hasil pemeriksaan feses dari dua kanguru pohon kelabu menunjukkan bahwa hewan tersebut terinfeksi oleh koksidia (Gambar 1A dan 1B). Kanguru secara umum dapat terinfeksi oleh beberapa jenis koksidia seperti Emeria spp. dan Isospora spp. Hasil sporulasi ookista menunjukkan terdapat

Diterima: 22-08-2021 | Direvisi: 25-09-2021 | Disetujui: 30-09-2021

(C) 2021 CC-BY-SA. Ini adalah artikel Open Access yang didistribusikan berdasarkan ketentuan dari Creative Commons Attribution ShareAlike 4.0 Interna tional License (https://creativecommons.org/licenses/by-sa/4.0/). 
empat sporokista yang masing-masing mengandung dua sporozoit (Gambar 1B). Hasil pemeriksaan tersebut, merupakan ciri dari ookista Eimeria spp. Laporan berkaitan spesies Eimeria pada kanguru pohon kelabu sangat terbatas. Spesies Eimeria yang dapat menginfeksi kangguru diantaranya adalah E. trichosuri, E. wilcanniensis, dan E. utahensis (Ernst et al. 2007; Yang et al. 2012). Namun, untuk memastikan spesies Eimeria yang menginfeksi perlu dilakukan pemeriksaan lanjutan, seperti pengukuran morfologi ookista, atau metode molekuler PCR.

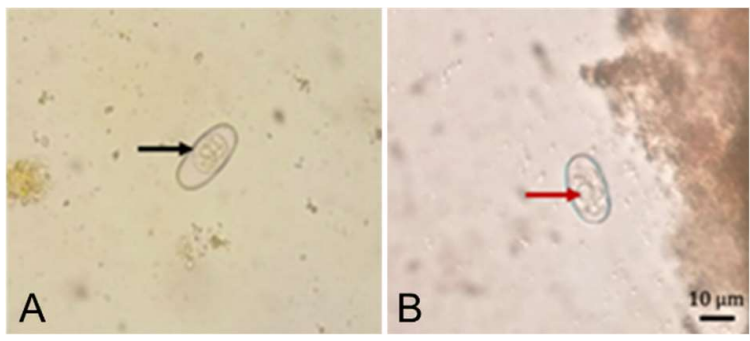

Gambar 1. Ookista Eimeria spp.: (A) Ookista belum bersporulasi (panah hitam) sporoblas, (B) Ookista setelah sporulasi (panah merah) sporokista. Ukuran ookista $(10 \times 25 \mu \mathrm{m})$.

Hasil pemeriksaan menunjukkan jumlah ookista dari kedua kangguru yang diperiksa adalah 400-500 ookista pergram tinja (OTGT). Jumlah ookista tersebut termasuk ke dalam kategori rendah. Menurut Bahrami \& Alborzi (2013) jumlah OTGT dapat dikategorikan menjadi tiga kelompok yaitu ringan $(<2500$ OTGT), sedang (2500-5000 OTGT) dan berat $(>5000$ OTGT). Jumlah ookista dalam feses dipengaruhi oleh strain koksidia, umur dan status kekebalan hospes, konsistensi sampel feses dan metode pemeriksaan. Pengamatan dilakukan oleh tim kesehatan dan keeper kanguru kelabu pada perilaku kanguru betina berumur 1,5 tahun yang menunjukkan penurunan aktivitas, lemah, lemas, dan nafsu makan menurun. Gejala tersebut merupakan gejala umumnya dari hewan yang terinfeksi oleh koksidia.

Faktor yang paling berperan pada transmisi koksidios adalah adanya kontaminasi ookista pada sumber air dan alas kandang atau tanah. Ookista yang keluar bersama feses dan bersporulasi memiliki dinding yang tahan terhadap desinfektan, seperti hipoklorit, cresol, dan formalin (Jatau et al. 2017). Faktor lainnya yang secara signifikan dapat mempengaruhi infeksi koksidiosis adalah stress. Pada umumnya kangguru merupakan hewan yang mudah mengalami stres termasuk kanguru pohon kelabu, hal ini dapat memicu peningkatan kerentanan terhadap infeksi parasit. Beberapa faktor pemicu stres diantaranya adalah nutrisi dari pakan, pakan yang tidak sesuai atau perubahan pakan, dan cuaca.

\section{- SIMPULAN}

Kedua kangguru pohon kelabu di konservasi ex situ terinfeksi oleh koksidia dari Eimeria spp. dengan derajat ringan. Pemeriksaan feses secara rutin dan sanitasi kandang sangat penting sebagai upaya pencegahan, khususnya untuk hewan yang dikandangkan bersama seperti di tempat pusat rehabilitasi dan tempat konservasi ex situ.

\section{- INFORMASI PENULIS}

Penulis untuk Korespondensi

*yridwan@apps.ipb.ac.id

Departemen Ilmu Penyakit Hewan dan Kesehatan Masyarakat Veteriner, Fakultas Kedokteran Hewan, Institut Pertanian Bogor. Jalan Agatis Kampus IPB Dramaga 16680, Dramaga, Bogor, Jawa Barat INDONESIA.

\section{- PUSTAKA ACUAN}

Barker IK, O'Callaghan MG, Beveridge I. 1988. Eimeria spp. (Apicomplexa: Eimeriidae) parasitic in wallabies and kangaroos of the genera Setonix, Thylogale, Wallabia, Lagorchestes and Dendrolagus (Marsupialia: Macropodidae). International journal for parasitology. 18(7):955-962.

Barker IK, O'Callaghan MG, Beveridge I. 1989. Host-parasite associations of Eimeria spp. (Apicomplexa: Eimeriidae) in kangaroos and wallabies of the genus Macropus (Marsupialia: Macropodidae). International Journal for Parasitology. 19(3):241-263.

Ernst JV, Hammond DM, Chobotar B. 1968. Eimeria utahensis sp. n. from kangaroo rats (Dipodomys ordii and D. microps) in northwestern Utah. The Journal of Protozoology. 15(3):430-432.

Jatau ID, Aremu SF, Magaji Y, Babashani M. 2017. Oocysticidal effects of some commercial poultry house disinfectants against sporulated Eimeria tenella oocysts. Journal of Animal Production Research. 29(2):281-288.

KLHK. 2018. Peraturan Menteri Lingkungan Hidup dan Kehutanan Republik Indonesia Nomor P.20/Menlhk/Setjen/Kum.1/6/2018 Tentang Jenis Tumbuhan dan Satwa yang Dilindungi.

Leary T, Seri L, Wright D, Hamilton S, Helgen K, Singadan R, Menzies J, Allison A, James R, Dickman C, Aplin K, Flannery T, Martin R, Salas L. 2016. Dendrolagus inustus. The IUCN Red List of Threatened Species.

O'Callaghan MG, Barker IK, Beveridge I, Hornsby P. 1998. Eimeria species in the Pearson Island rock wallaby, Petrogale lateralis pearsoni. International Journal for Parasitology. 28(12):1889-1892.

Bahrami S, Alborzi AR. 2013. Prevalence of subclinical coccidiosis in river buffalo calves of southwest of Iran. Acta Parasitologica. 58(4):527-530.

Yang R, Fenwick S, Potter A, Elliot A, Power M, Beveridge I, Ryan U. 2012. Molecular characterization of Eimeria species in macropods. Experimental Parasitology. 132(2):216-221. 